\title{
The praxis of ethics and justice in human rights learning: examining the limits of progressive education
}

\author{
Rebecca Adami ${ }^{1}$
}

Published online: 31 August 2016

(C) The Author(s) 2016. This article is published with open access at Springerlink.com

\begin{abstract}
School and education can be seen as an extension of the home as Hannah Arendt stresses, where children are protected in a space in which they can learn and grow, a space that is not yet public. This distinction of education as "not yet public" can be seen in contrast to John Dewey who explores notions of democracy as a process in education, where education and school is regarded as a mini society. This paper explores several challenges with progressive education and, specifically, of human rights education, through the work of Arendt (1959) and Dewey (1990) on the notions of responsibility and children's human rights. Where do we as educators draw the distinction between taking responsibility of raising awareness of global injustices and human rights violations with the next generation without falling pray to dissolution that the gap between political imaginary and reality faces us with, or risking violating children's "safe space" in school that according to Arendt should be a space that is neither private nor public, but a free zone for thinking and learning with others? Do we bring into the classroom discrimination and segregation by drawing on social categorizations with the pretext of questioning the same on the basis of "equal rights"? If ethical and relational dimensions of education are to be taken seriously then human rights education is a risky practice since it involves children's sense of being and it raises questions that may not be dealt with properly or solvable for the children exposed.
\end{abstract}

Keywords Childrens' rights · Hannah Arendt · John Dewey · Progressive education · Political subject

\section{Introduction}

As educators we face the inherent challenges of teaching about justice in a society fraught with social and racial discriminatory practices. How can we talk to pupils in a

Rebecca Adami

Rebecca.adami@edu.su.se

1 Department of Education, Stockholm University, Stockholm, Sweden 
responsible and yet empowering way about segregation and discrimination, when children lack the political rights to challenge injustice created by political inequality? How do we create a meaningful understanding of the notion of the "right to life" when the legal system upholds the death penalty - even of minors - and law enforcement does not sanction violence against minorities but rather legitimizes such practices through promulgating notions of "lawful killing"?

These are some of the problems that we educators face in approaching notions of social justice when the social reality exhibits endless instances of political and social injustice. These questions point to the limits of progressive education and to the external skepticism of Human Rights Education. In an article entitled "Reflection on Little Rock" ${ }^{1}$ Hannah Arendt (1959) raises some concerns regarding progressive education as a means to pursue societal change beginning in elementary school. Arendt's article is a critical response to the legal efforts made in the US in the nineteen-fifties to desegregate public schools. Arendt asks why children are forced, through the desegregation of public schools, to become figure heads in of a societal problem that should be dealt with in the political arena between equals, not to be played out on school yards by children who simply need a safe space in which to learn.

In this paper I will examine the limits of progressive education through the critique raised by Arendt on adult responsibility in terms of their primary role to create political change for social justice. Arendt's critique illustrates the limits of pushing for change through education when children lack political rights and freedoms; this critique may help us to address the hypocrisy many educators feel when attempting to reconcile the hopes of pupils, the delusion of adults and the utopian notion of human rights as basis for social community.

John Dewey (1990) contends that social revolution can start at school and through democratic education one can improve society and develop democracy. The challenge of Human Rights Education, as with progressive education, is how to teach about a political utopia in a world marked by discriminatory practices and structures of social oppression? Brian Orend (2008) has criticized Human Rights Education in North America for being taught as already fait compli - taught, in other words, through the notions of civil rights and with reference to national jurisdiction and the American Bill of Rights, rather than problematizing the national politics and laws relative to the international definitions of human rights in the United Nations. Franklin Roosevelt played a primary role in the creation of the United Nations as he had a vision that long lasting peace could be created if countries small and large could meet on equal, diplomatic footing in an international arena. His wife, Eleanor Roosevelt, played an influential role in the drafting of the Universal Declaration of Human Rights in 1948, when delegates from over fifty-six countries met on American soil to discuss the definition of human rights in thirty articles that later became a common declaration that today has received customary law status. At the time of the drafting of the Universal Declaration of Human Rights, the American delegation received heavy criticism from other countries for their discriminatory practices of racial segregation, alongside the South African delegation, which at the time upheld the oppressive system of apartheid. Eleanor Roosevelt argued that the declaration was not perfect, but that the

\footnotetext{
${ }^{1}$ The Little Rock Nine were a group of nine African American students enrolled in Little Rock Central High School in 1957.
} 
American delegation stood behind it. Since then the political climate in the US seems to have shifted as international standards of human rights are not generally referred to as a project that the US initially supported and even initiated. Today Human Rights Education, as Orend (2008) stresses, is taught in the US with national references to the Bill of Rights and the concept of civil rights. The drafters of the American Constitution did not intend civil rights to include either the African American population or women as citizens of equal political freedoms in the US. The persistent inferiority of minorities', women's, and children's political and social rights relative to the white man suggests to us that Roosevelts' initial vision may exceed the legal and political definitions of today. The notion of human rights is not fully actualized but is only partly a social reality as a proclamation for the future. How, as Dewey suggests, can teachers instill ideas of democracy when there exists a lack of such redundant praxis in society? According to Arendt, political visions of social justice should not be carried out through public education, but concerns of equality belong to the political sphere where adults are responsible for political enactments in the public arena. Human Rights Education would, in Arendt's view, be a way to place upon the next generation - through education - political responsibilities that adults should be obliged to face. Though public schools are a part of the public sphere, adults often evade their responsibility by foisting social issues upon schools.

\section{Dewey, democracy and progressive education}

Dewey (2005) questions the understanding that there exist societies that can ever become fully "civilized" or "democratic". Similarily, according to Dewey, the"democratic practices" in education are as flawed as our understanding and democratic experiences in society. This questioning opens up the possibility to look beyond common understandings that certain societies are in total harmony with the notion of human rights while others are in constant conflict as the result of differing value systems. When we question, as Dewey does, that the US is already civilized and that all its political and legal practices reflect a civilized society as a fait compli, we argue that democracy is a constant process that can always be improved. This points also to how educational possibilities are constrained by the very societies in which learning for democracy and human rights is being promoted.

This relative openness to the ideological justifications of rights as un-conflated with a certain ideological and political perspective offers interstices for discussions and negotiations on the moral justification of rights and on the political action needed to realize these rights. For what room is there for receptivity in teachers engaging in processes of change with students if ethics and justice are taught as conflated with a certain political ideology? (Adami 2014c) Dewey asks educators to be visionary in their political outlook on society and the improvement of democracy. He argues that 'What the best and wisest parent wants for his own child, that must the community want for all of its children. Any other ideal for our schools is narrow and unlovely; acted upon, it destroys our democracy' (Dewey 1990, 7). This notion of education as the mode of visionary teaching to create a better democratic society is what has been taken up in Dewey's writings in recent policy reports and teaching materials on Human Rights Education and in Education for Democratic Citizenship. In a manual for teachers 
published by the Council of Europe, Peter Krapf, Rolf Gollob and Wiltrud Weidinger (2010) base their understanding of Human Rights Education on Dewey's notion of teaching, to create democratic citizens who will become involved in changing society. 'Decision-making processes in democracies are essentially collective processes of learning. This is the reason why John Dewey conceived of school "as a miniature community, as an embryonic society" (Krapf et al. 2010, 19). According to Krapf et.al, to educate about human rights is rather to engage in democratic praxis. Educators should - in this view - listen to and facilitate student initiatives in creating forums within the school to practice democratic participation. By learning how to raise their voices on issues concerning their rights and by collectively engage in democratic processes students become aware of their human rights. ${ }^{2}$ Another publication from the Council of Europe mentions Dewey when discussing Human Rights Education,

In accordance with Dewey's vision of "schools as a democratic space", teachers might seek to provide students with opportunities to develop their civic attitudes and behavior by working on school-based or community projects. The main purpose of this broader conception of EDC/HRE is to encourage students to exploit what they have learnt about EDC/HRE and to transfer their cognitive and social skills to practical and active participation. (Brett et al. 2009, 48)

Again, the focus in Human Rights Education that is here based on ideas developed by Dewey, which are focal for progressive education; to learn through praxis, that students should be given the opportunity to enact their democratic influence and participate actively in society through community service projects. Through this experience they will gain the variety of knowledge that Dewey speaks of as not just the mere gathering of information and facts, but lived experience that enables students to make meaning of notions of rights and justice. The paradox in these instructions and handbooks for educators lies in the fact that students, as minors, lack the actual political rights and freedoms they are supposed to enact. Human Rights Education can be seen as an imaginary for a future in which students are able, as adults, to politically impact their own situatedness, as such human rights learning prepares children for what lies ahead. Children have very little influence over their social environment, as they are dependent economically and socially on parents, guardians and other adults for their daily wellbeing and realization of social and economic rights. Children do not have the right to choose their own schooling, they do not have the right to choose where to live or to have any political opinion on the rules, laws and political practices of the society in which they live.

Peter Brett et.al (2009) illustrate what this kind of learning can mean by the example of letting children imagine a person and a wizard in order to express their ideal world and wishes for a more just society. The educator should ask the children what they

\footnotetext{
${ }^{2}$ In their writing, Krapf et.al use the concepts of Human Rights Education and Education for Democratic Citizenship interchangeably, which one sees in both national and European research in the field. Even though its not a main argument I intend to raise in the paper, I want to distinguish between the two, since the notion of citizenship is tied to discourses on nationality and the state, connected to borders, whereas human rights is more connected to utopian perceptions of belonging, where the human dignity, rather than citizenship, is the main basis for entitlement.
} 
think that the wizard would do in different situations. The wizard can of course do anything. The person is limited to the abilities that human beings are bound by. I want to mention this illustration here to further emphasize the critique that Arendt (1959) raised against the limits and potential harm with progressive education. Children are in this instance instructed to think about situations where they have felt powerless, where their human rights have not been respected and then visualize what they would have done if they were the wizard. The intention with the practice is to make children think positively and imagine solutions to problems they might feel incapable to do anything about. Here, the potential harm is that children are still in their disempowered position after the exercise but even more acutely aware of the injustices that they are not able to do much about. The reason why the fiction book Harry Potter is so popular is because he actually was a wizard - not forced back into the cupboard by his mean foster parents but with the possibility to leave for a school for wizards. Teaching about human rights involves addressing social injustices and acknowledging the gap between a utopian notion and the social reality win which discrimination rather than equality informs people's actions. If, as educators, we take seriously the human rights of children, then how are we teacher supposed to deal-alongside students - issues of child abuse, neglect and other forms of disrespect toward children's human rights? Are we ready to stand up the oppression of children in our own communities when the perpetrators of children's human rights might be a colleague, a friend, a parent, or a principal? The risk of pursuing progressive education is to be faced as an educator with children's narratives of human rights violations, and what the responsibility then is for the educator who engages in human rights learning with her/his students? This risk, I argue, is placed back on the child, the student, by rhetoric of the learner's capacity to "pursue positive change".

Drawing on the work of John Dewey, Paolo Freire and other progressive theorists, Human Rights Education ideally represents both a deepening of student understanding about the content of human rights (historic and contemporary), and a set of skills that can inspire learners to pursue positive social change. (Fernekes, William 2014)

Even though this visionary view of education as a means to change society is crucial in Dewey's writing and for Human Rights Education, Dewey's contributions to the conceptualization of Human Rights Learning extend further.

\section{Human rights education as conversation through difference}

Human rights have been criticized as a Western, liberal project, incompatible with other non-Western moral and ideological systems (Cohen 2004; Ignatieff and Gutmann 2003). Based on this understanding human rights violations are generally discussed in relation to non-Western countries and seldom used to critically examine Western societies (Mutua, Makau 2002; Schumann and Adami 2014). Human Rights Education when fused with certain political or moral claims does not become a learning project but rather a project of persuasion in classrooms of diversity (Adami 2014b). As David Hansen (2006) writes, 'For Dewey, no education can be moral unless it cultivates the 
capacity to criticize intelligently' (2006, 15). According to Dewey (1938) education should encompass a sense of morality that is not reduced to a single set of values but instead concerns all human interactions. In United Nations international documents Human Rights Education has been described as concerning the right to education-for social justice and peaceful ways of living together in a world of cultural, religious, and ideological difference.

Dewey (1938) proposes education as one based on conversation on experience, in which the problems and challenges of society are the common basis of discussion. As such, Human Rights Education may be concerned not only with the praxis of democratic participation in society as a whole (in order to move society toward greater justness and inclusiveness), but equally concerned with conversation across cultures through the unique experiences of the involved ones.

A Human Rights Educator is challenged with how to teach about politically utopian ideas in a world marked with colonial practices and well-established structures of social oppression. Brian Orend (2008) examines some of these challenges for Human Rights Educators in North America, such as their focus on domestic or national civil liberties legislation, its under-emphasis on international human rights and an overly legalistic view that neglects the political and social dimensions of human rights.

The notion of human rights may be an inspiring and empowering narrative for teachers, but can we really look to progressive education to change society? What are the limits for progressive education in creating equality? According to Arendt (1959), progressive education abolishes the authority of adults, denying the responsibility over politics and the world into which they should be introducing the children. The political project should hence be one undertaken between equals in a public arena. Susan Bickford (1995) raises a feminist concern on who's voice is being listened to or not in public. Arendt argues that it is the unique voice and not the particularity of a person that should be listened to in politics. It is not what social category a person can be described as that should matter in public appearances, but who one is. Bickford pays attention to power and discrimination in raising the "paradox of public appearance", stating that even though women may want to speak from their particularity as woman in public, the problem is not "the characteristics themselves, but the kind of attention paid to them" as "racism, sexism, class discrimination, and heterosexism influence who gets paid attention to, what gets heard, and how" (Bickford 1995, 318). What Arendt is concerned with, especially in her text on Little Rock, is nevertheless not how racism gets played out in a segregating school system but how children had to take up political roles where adults failed in creating equality through politics. Jean Bethke Elshtain (1995) raises some valuable critique in regard to Arendt's unwillingness to see children as political. Elshtain illustrates how children have been taking part in revolutions in history, the Civil Rights Movement being one of those occasions where the political actions of children helped raise awareness and fueled white people to act against the arrest of thousand Afro American children who were being jailed by police in peaceful marches $(1995,275)$. Elshtain argues that the children were already risking their lives due to racism, discrimination and killings of innocent people in the segregated South. Whether children are being used by adults in their actions is something Elshtain raises but what she, and Arendt, do not challenge, is how adults both put a lot of faith and moral pressure on the new generation, while simultaneously letting children live as non-equals, not political, but being put in youth prisons, being killed and tortured, used 
as soldiers, abused and neglected, without neither legal nor political power to question these forms of oppression of their human rights by adults who should, according to Arendt, protect them. Arendt sees school as part of the private sphere where they should be protected against politics. Although one could also describe the school as "part of the private sphere" in the protection that teachers and caretakers are to provide for children, it can also be seen as "part public sphere" since children in school are faced, directly and indirectly with politics, social values, moral and religious agendas and utopian visions by adults who run school and politics.

\section{Learning human rights through narrativity}

From the standpoint of the child, the great waste in the school comes from his inability to utilize the experiences he gets outside the school in any complete and free way within the school itself; while, on the other hand, he is unable to apply in daily life what he is learning at school. That is the isolation of school, the isolation from society. (Dewey 1990, 75)

According to Dewey (1990) a gap exists between what children learn at school and the experiences they bring to school: there is a gap between what they learn and how they can use and act on this new knowledge in their daily lives. In the realm of Human Rights Learning, there is a risk that learning about one's human rights can be harmful for a child without tools to change his/her social reality. A student who is abused at home and who learns about her/his human right to freedom from torture (if interpreted as in the Convention of the Rights of the Child as including the freedom from rape and physical abuse of children) cannot escape from that daily reality by virtue of having learned about their rights. Especially, since the human rights of the child may be in conflict with the interests of adults to keep children inferior, such awareness may only increase a child's sense of powerlessness.

Dewey points to a critique of schooling as existing separately from daily concerns institutionalized to the point of total isolation from a child's social reality. Dewey criticizes the way in which education has come to praise abstract thinking that children cannot connect to any experience outside school. As children may experience abuse, neglect, and general treatment as a being without having political rights, the experiences that children have are not verbalized in school. Thus the mind of an abused child may wander in other directions rather than focus on abstract thinking. 'If he had a purely abstract mind, he could bring it to school with him, but his is a concrete one, interested in concrete things, and unless these things get over into school life he cannot take his mind with him.' (Dewey 1990, 80)

A narrow rights based curriculum - poorly contextualized in the larger moral and aesthetic concerns of the formation of a genuine learning community-could do children great harm. There is a risk of putting the student in a harmful situation by educating them about rights that concern the student's life experiences but fails to provide the tools for the student to change that situation. Both the political and legal systems remain out of reach for a child that lacks political rights and who is not regarded as equal in society. And if the ideal envisioned through Human Rights Learning is greatly at odds with the lived reality in which discrimination, violence 
and inequality are persistent, then where does that leave educators who might want to dedicate time and effort to alternative forms of Human Rights Learning?

This positions educators at the limits of progressive education. At these outskirts, however, we may discover new insights by which we can read Dewey through Arendt's notion of narrativity, relational responsibility and the ontological process of becoming. In Education and Experience, Dewey (1938) argues that there is a need for a theory predicated upon experience. He criticizes the way that progressive education is dealt with as an "ism" arguing that we should instead consider education as a process in constant flux. Following Dewey's rejections of "isms" we should turn our focus toward experience and change narratives. We might explore learning as a conversation on experience or as narrativity (Adami 2014b). Though students may feel disempowered in learning about human rights while they lack the political capacity to change the rules and laws that prevail in society, there nevertheless exists the possibility for students to learn about human dignity and what it means to be human through respectful communication with educators.

I am certainly not alone in having met a teacher who I felt helped me to expand my perception of myself and what I held as possible for my future. Though both the teacher and I were powerless to change the social reality of certain forms of oppression the educator still saw, listened and created a space where my voice was empowered through the experience of narrating and getting to know myself through that reclaimed voice.

At the outskirts of progressive education is Dewey's notion of learning through voicing relational experience because even though the process of democratic change may be out of reach for children, the process of becoming is not. As narrativity is relational the educator, I argue, plays a crucial role in the ways aesthetics and morals (in Dewey's broader notion of morality) infuse ontological processes of becoming.

In this final part of the paper I draw more closely upon Dewey's understanding of education as conversation - a reading of Dewey shared with Gert Biesta (2006). Here, the difference is that I am reading Dewey's understanding of education as conversation on experience through Arendt's notion of narrativity. By doing so I explore Human Rights Learning at its limits by emphasizing Dewey's stress on moral education as encompassing all human encounters and the presumed value conflicts, power structures, and vulnerability that come with communicative relations across difference (a view shared with David Hansen 2006). By revoking Dewey's work along with the critique of progressive education offered by Arendt, there emerges a new conceptualization of Human Rights Learning and the potential for change in narrativity as the sharing of experience across cultural and social difference.

There is a transformative potential of relational narrativity. The process of learning through conversation - through the exposure of oneself in relation is, in Dewey's view, a way of experiencing something again though differently and in the course of explaining this experience to someone else, our own understanding of our self transforms. In Arendt's words we are in constant narrativity, and in the course of speaking about our lives (even the most violent events) we learn to become human. This is not a process of learning about another (as Martha Nussbaum 1998 has explored), or learning from another (as in writings by Sharon Todd 2003) but learning in relations; about who we are and who we become in the course of narration (Adami 2014a, b). According to Dewey (2005): 
The experience has to be formulated in order to be communicated. To formulate requires getting outside of it, seeing it as another would see it, considering what points of contact it has with the life of another so that it may be got into such form that he (she) can appreciate its meaning.(Dewey 2005, 5-6)

It can be a very powerful experience for students when educators are able to create safe spaces in which such encounters with unique others and with one's own narrated life experiences are actively listened to by both the other and oneself. The enhanced learning of human rights that I am putting forth here is not a learning about anotherabout victims who live far away from one's own community-but a learning about one's own experiences through the notions of dignity and rights. The reason why I refer to this as enhanced understanding of human rights is that human rights, when discussed as mere articles in a document, are no more than abstract words, but when formulated through the unique experiences of a human being and when communicated to a distinct other, the meaning of human rights "come alive".

Dewey additionally stresses morals as not merely a set of values but rather as fundamental to all human encounters. In Human Rights Education, if human rights are merged with one ideological perspective or with one outlook on the world, the relations between educator and student may be characterized as colonial, as missionary (Dembour 2006). Missionary tendencies exhibit a lack in critical ability as part of a self-ignorance - as a non-critical view of the here implies a one-sided view of the other. In a relational notion of learning human rights, the educator is involved in this process of becoming, is equally vulnerable and exposed in narration. As such, they are in selfdoubt when the structures that uphold discriminatory and harmful practices become transparent in the course of narrating experiences of human rights. Human Rights Learning along these lines of thought would entail a criticality of colonial structures and practices since moral education is as much how the pedagogy is practiced as what the educator is talking about. This pedagogical practice is not a one-dimensional action of the teacher, but is created in relations. Biesta (2006) reads the relational focus in Dewey's writings:

For Dewey, the meaning of the world is, after all, not located in the things and events themselves, but in the social practices in which things, gestures, sounds, events play a role. We could therefore say that because meaning only exists in social practices, it is, in a sense, located in-between those who constitute the social practice through their interactions. (Biesta 2006, 31-32)

In this view, adults responsibilities encompass more than mere classroom situations. They include efforts against bullying and discrimination, efforts against violence and power domination and efforts to give students democratic influence over their situation in school as vital to the education. Public schools are part of the public sphere and there are concerns of social justice actualized in this sphere. The political responsibility is on teachers as adults, who, in contrast to children, have political agency through the political rights and freedoms that only adults are privileged with.

So what can we gain from progressive education? How can we deal with human rights learning in a way that is actually empowering? Learning human rights through one's own life narrative is a voicing of what human rights can mean in 
the home, in the political and social environment in which one is relationally ensconced but the focus of the learning process is not explicitly to change this possibly unequal society but rather a process of becoming where the self is exposed through the narration of experiences of human rights. According to Dewey, relational voicing of experience is educative in itself and as this concerns moral education, these encounters must bear the praxis of ethics and justice.

Open Access This article is distributed under the terms of the Creative Commons Attribution 4.0 International License (http://creativecommons.org/licenses/by/4.0/), which permits unrestricted use, distribution, and reproduction in any medium, provided you give appropriate credit to the original author(s) and the source, provide a link to the Creative Commons license, and indicate if changes were made.

\section{References}

Adami, Rebecca. 2014a. Human rights learning: The significance of narratives, relationality and uniqueness. Doctoral Thesises from the Department of Education, 28. Stockholm: Stockholm University Press.

- 2014b. Re-thinking relations in human rights education: the politics of narratives. Journal of Philosophy of Education 48(2): 293-307.

- 2014c. Towards cosmopolitan ethics in teacher education: an ontological dimension of learning human rights. Ethics and Education 9(1): 29-38.

Arendt, Hannah. 1959. Reflections on Little Rock. Dissent 6, no.1 (1959). 45-56.

Bethke Elshtain, Jean. 1995. Political Children. In Feminist Interpretations of Hannah Arendt, ed. Bonnie Honig, 263-84. University Park: The Pennsylvania State University Press.

Bickford, Susan. 1995. In the presence of others: arendt and anzaldúa on the paradox of public appearance. In Feminist Interpretations of Hannah Arendt, ed. Bonnie Honig, 313-36. University Park: The Pennsylvania State University Press.

Biesta, Gert. 2006. 'Of all affairs, communication is the most wonderful': The communicative turn in Dewey's democracy and education. In Prospect, ed. John Dewey and Our Educational, 23-38. New York: State University of New York Press.

Brett, Peter, Pascale Mompoint-Gaillard, and Maria Helena Salema. 2009. How All Teachers Can Support Citizenship and Human Rights Education: A Framework for the Development of Competences. Council of Europe.

Cohen, Joshua. 2004. Minimalism about human rights: the most we can hope for? The Journal of Political Philosophy 12(2): 190-213.

Dembour, Marie-Bénédicte. 2006. Who believes in human rights? : Reflections on the European convention. Law in context. Cambridge: Cambridge University Press.

Dewey, John. 1938. Experience and education. New York: Kappa Delta Pi.

1990. The school and society. Chicago \& London: The University of Chicago Press.

2005. Democracy and education : An introduction to the philosophy of education. New York: Cosimo Classics.

Fernekes, William. 2014. Prospects and possibilities for HR education in the US. The Volunteer.

Hansen, David T. 2006. John Dewey and our educational prospect. New York: State University of New York Press.

Ignatieff, Michael, and Amy Gutmann. 2003. Human rights as politics and idolatry. University center for human values series. Princeton: Princeton University Press.

Krapf, Peter, Rolf Gollob, and Wiltrud Weidinger. 2010. Taking part in democracy: Lesson plans for upper secondary level on democratic citizenship and human rights education. Council of Europe.

Mutua, Makau. 2002. Human rights: A political and cultural critique. University of Pennsylvania Press.

Nussbaum, Martha Craven. 1998. Cultivating humanity: A classical defense of reform in liberal education. Cambridge: Harvard University Press.

Orend, B. 2008. Human rights education: Form, content and controversy. Encounters on Education 5: $61-80$. 
Schumann, Claudia, and Adami, Rebecca. 2014. Towards a critical cosmopolitanism in human rights learning: The Vienna conference in 1993. Philosophy as lived experience. Navigating through dichotomies of thought and action. Berlin: VDM Verlag.

Todd, Sharon. 2003. Learning from the other : Levinas, psychoanalysis, and ethical possibilities in education. SUNY series, second thoughts. Albany: State University of New York Press. 